AKRUAL 4 (2) (2013): 105-118 $e$-ISSN: 2502-6380

AKRUAL

Jurnal Akuntansi

http://fe.unesa.ac.id/ojs/index.php/akrl

\title{
PENGARUH FREE CASH FLOW DAN KUALITAS AUDIT TERHADAP MANAJEMEN LABA
}

\author{
Dian Agustia \\ Fakultas Ekonomi dan Bisnis Universitas Airlangga \\ E-mail: agustiadian_feb@yahoo.com \\ Artikel diterima: 12 Desember 2012 \\ Terakhir direvisi: 20 Januari 2013
}

\begin{abstract}
Asymmetric information refers to a situation where one party has more information than the other party. The agency problems arise from asymmetric information in the principal agent contracts. In addition, there are also several factors that could affect earnings management that is free cash flow and audit quality. The aim of this research is to provide empirical evidence about the impact of free cash flow and audit quality variables on discretionary accruals, as a measure of Earnings Management with the control variables company's size. This research used 103 manufacturing companies listed in Indonesia Stock Exchange, selected using purposive sampling method, during the research period 2007-2011. Data were analyzed using multiple regression method. Based on the result of analysis concluced that the variable independent free cash flow have a negative and significant effect on earning management. It means that companies with high free cash flow will restrict the practice of earnings management. While the audit quality no significance effect on earning management.
\end{abstract}

Keywords: Free cash flow, audit quality, earnings management.

\section{PENDAHULUAN}

Salah satu elemen penting dalam laporan keuangan yang digunakan untuk mengukur kinerja manajemen adalah laba. Informasi laba merupakan perhatian utama untuk menaksir kinerja atau prestasi manajemen. Selain itu informasi laba juga digunakan oleh investor atau pihak lain yang berkepentingan sebagai indikator efisiensi penggunaan dana yg tertanam dalam perusahaan yang diwujudkan dalam tingkat pengembalian dan indikator untuk kenaikan kemakmuran (Ghozali dan Chariri, 2007:350). Adanya asimetri informasi dan kecenderungan dari pihak eksternal (investor) untuk lebih memperhatikan informasi laba sebagai parameter kinerja perusahaan akan mendorong manajemen untuk melakukan manipulasi dalam menunjukkan informasi laba, yang disebut sebagai manajemen laba (earnings management). Timbulnya manajemen laba dapat dijelaskan pula dengan teori agensi. Sebagai agen, manajer secara moral bertanggung jawab untuk mengoptimalkan 
keuntungan para pemilik (principal) dan sebagai imbalannya akan memperoleh kompensasi sesuai dengan kontrak. Manajemen laba menurut Scott (2011:423) adalah "the choice by a manager of accounting policies so as to achieve some specific objective". Hal ini berarti manajemen laba merupakan keputusan dari manajer untuk memilih kebijakan akuntansi tertentu yang dianggap bisa mencapai tujuan yang diinginkan, baik itu untuk meningkatkan laba atau mengurangi tingkat kerugian yang dilaporkan. Menurut Scott (2011:426) beberapa motivasi yang mendorong manajemen melakukan earning management, antara lain adalah (1) Motivasi bonus, yaitu manajer akan berusaha mengatur laba bersih agar dapat memaksimalkan bonusnya; (2) Hipotesis perjanjian hutang (Debt Covenant Hypothesis), berkaitan dengan persyaratan perjanjian hutang yang harus dipenuhi, laba yang tinggi diharapkan dapat mengurangi kemungkinan terjadinya pelanggaran syarat perjanjian hutang; (3) Meet Investors Earnings Expectations and Maintain Reputation, perusahaan yang melaporkan laba lebih besar daripada ekspektasi investor harga sahamnya akan mengalami peningkatan yang signifikan karena investor memprediksi perusahaan akan mempunyai masa depan yang lebih baik; (4) IPO (Initial Public Offering), manajer perusahaan yang akan go public termotivasi untuk melakukan manajemen laba sehingga laba yang dilaporkan menjadi tinggi dengan harapan dapat menaikkan harga saham perusahaan.

Perusahaan dengan arus kas bebas (free cash flow) yang tinggi akan memiliki kesempatan yang lebih besar untuk melakukan manajemen laba, karena perusahaan tersebut terindikasi menghadapi masalah keagenan yang lebih besar (Chung et al., 2005). Penelitian sebelumnya menunjukkan bahwa perusahaan dengan surplus arus kas bebas yang tinggi juga cenderung melakukan praktik manajemen laba dengan meningkatkan laba yang dilaporkan untuk menutupi tindakan pihak manajer yang tidak optimal dalam memanfaatkan kekayaan perusahaan (Bukit dan Iskandar 2009). White et al. (2003:68) mengungkapkan bahwa semakin besar free cash flow yang tersedia dalam suatu perusahaan, maka semakin sehat perusahaan tersebut karena memiliki kas yang tersedia untuk pertumbuhan, pembayaran hutang, dan deviden. Free cash flow merupakan determinan penting dalam penentuan nilai perusahaan, sehingga manajer perusahaan lebih terfokus pada usaha untuk meningkatkan free cash flow (Sawir, 2004:94).

Kualitas audit dengan proksi ukuran KAP, merupakan salah satu indikator yang dapat untuk mendeteksi manajemen laba. Pada KAP yang lebih besar (big four) diasumsikan audit yang dilaksanakan lebih berkualitas dibandingkan dengan KAP yang lebih kecil (non big four) karena adanya kecenderungan untuk lebih berhati-hati dalam melaksanakan audit, sehingga kecenderungan pihak manajer untuk melakukan praktik manajemen laba akan lebih kecil (Gerayli, 2011). 


\section{KAJIAN PUSTAKA DAN PENGEMBANGAN HIPOTESIS Manajemen Laba}

Belkaoui (2004:201) menyatakan pada dasarnya definisi operasional dari manajemen laba adalah "potensi penggunaan manajemen akrual dengan tujuan memperoleh keuntungan pribadi". Sedangkan, definisi manajemen laba menurut Scott (2011:423) adalah "the choice by a manager of accounting policies so as to achieve some specific objective". Hal ini berarti manajemen laba merupakan keputusan dari manajer untuk memilih kebijakan akuntansi tertentu yang dianggap bisa mencapai tujuan yang diinginkan, baik itu untuk meningkatkan laba atau mengurangi tingkat kerugian yang dilaporkan.

Sulistiawan dkk. (2011:51) menjelaskan bahwa kebijakan akrual dapat dibagi menjadi dua yaitu nondiscretionary accruals merupakan bagian akrual yang berubah bukan karena kebijakan atau pertimbangan pihak manajemen, seperti perubahan piutang yang besar karena adanya tambahan penjualan yang signifikan, dan discretionary accruals atau abnormal accruals yaitu bagian akrual yang dapat berubah sesuai dengan kebijakan manajemen untuk melakukan manajemen laba.

Secara umum ada tiga pendekatan yang telah dihasilkan para peneliti untuk mendeteksi manajemen laba, yaitu model yang berbasis agregate acrrual, spesific accruals, dan distribution of earnings after management. Dalam penelitian ini, lebih memfokuskan pada penggunaan model pendekatan berbasis aggregate accrual, yaitu model yang digunakan untuk mendeteksi aktiva rekayasa dengan menggunakan discretionary accruals sebagai proksi manajemen laba. Sulistyanto (2008:165) menjelaskan bahwa secara empiris nilai discretionary accruals bisa nol, positif, atau negatif. Nilai nol menunjukkan manajemen laba dilakukan dengan pola perataan laba (income smoothing), sedangkan nilai positif menunjukkan bahwa manajemen laba dilakukan dengan pola penaikkan laba (income increasing), dan nilai negatif menunjukkan manajemen laba dengan pola penurunan laba.

\section{Free Cash Flow}

Arus kas bebas (Free cash flow) adalah "arus kas aktual yang didistribusikan kepada investor sesudah perusahaan melakukan semua investasi dan modal kerja yang diperlukan untuk menjaga kelangsungan operasionalnya" (Sawir, 2004:93). Hipotesis arus kas bebas (Mardiyanto, 2008:281) menjelaskan bahwa "perusahaan yang sanggup membagikan deviden lebih tinggi akan naik harga sahamnya karena dipandang investor sebagai perusahaan yang mempunyai kelebihan kas (free cash flow)". Perusahaan yang menahan kelebihan kasnya (tidak membagikannya sebagai deviden) justru harga sahamnya cenderung turun karena investor menganggap kelebihan dana tersebut akan dipergunakan untuk membiayai investasi yang kurang menguntungkan. Free cash flow merupakan determinan penting dalam penentuan nilai perusahaan, sehingga manajer perusahaan lebih terfokus pada usaha untuk meningkatkan free cash flow (Sawir, 2004:94). 


\section{Kualitas Audit}

Kualitas audit ditentukan oleh dua hal, kompetensi dan independensi. Kualitas ini mempunyai pengaruh langsung terhadap kualitas audit. Selain itu, laporan keuangan menggunakan persepsi bahwa kualitas audit adalah suatu fungsi untuk menggambarkan independensi auditor dan keahlian auditor tersebut (AAA FASC, 2001).

DeAngelo (1981) menjelaskan bahwa kualitas audit secara langsung berhubungan dengan ukuran dari perusahaan audit, dengan proksi untuk ukuran perusahaan audit adalah jumlah klien. Perusahaan audit yang besar adalah dengan jumlah klien yang lebih banyak. Hasil penelitiannya menunjukkan bahwa perusahaan audit yang besar akan berusaha untuk menyajikan kualitas audit yang lebih baik dibandingkan dengan perusahaan audit yang kecil. Karena perusahaan audit yang besar jika tidak memberikan kualitas audit yang tinggi akan kehilangan reputasinya, dan jika ini terjadi maka dia akan mengalami kerugian yang lebih besar dengan kehilangan klien. Gerayli (2011) menyatakan bahwa "auditor yang memiliki kualitas lebih baik cenderung untuk tidak menerima metode akuntansi yang tidak jelas dan lebih mampu untuk mendeteksi kesalahan dan penyimpangan”.

\section{Hipotesis}

\section{Pengaruh Free Cash Flow Terhadap Manajemen Laba}

Arus kas bebas (FCF) perusahaan yang tinggi tanpa adanya pengawasan yang memadai bisa terjadi karena pihak manajer tidak memanfaatkan secara optimal kas yang tersedia secara tepat, atau menggunakannya untuk investasi yang menguntungkan dirinya sendiri. Hal ini berdampak pada peningkatan praktik manajemen laba untuk meningkatkan pelaporan laba, sehingga adanya ketidakefisienan dalam penggunaan arus kas tersebut bisa tertutupi (Bukit dan Iskandar 2009). Tetapi hasil tersebut berbeda dengan penelitian Isnawati (2011:57) yang mengungkapkan bahwa perusahaan yang memiliki FCF tinggi justru berpengaruh negatif terhadap praktik manajemen laba, Berdasarkan uraian tersebut, dalam penelitian ini diajukan hipotesis sebagai berikut:

\section{$\mathrm{H}_{1}$ : Free cash flow berpengaruh terhadap manajemen laba.}

\section{Pengaruh Kualitas Audit Terhadap Manajemen Laba}

Gerayli (2011) menyatakan bahwa "auditor yang memiliki kualitas lebih baik cenderung untuk tidak menerima metode akuntansi yang tidak jelas dan lebih mampu untuk mendeteksi kesalahan dan penyimpangan”. Kualitas auditor tersebut diproksikan dengan ukuran KAP tempat auditor bekerja. KAP yang berafiliasi dengan KAP big four dianggap bisa menyediakan kualitas audit yang lebih tinggi dibandingkan dengan KAP yang tidak berafiliasi dengan big four (Guna dan Herawaty, 2010). KAP big four mempunyai insentif yang kuat untuk menjamin kualitas audit yang diberikan karena beberapa faktor, diantaranya yaitu KAP big four tersebut memiliki lebih banyak modal, pengalaman, sumber daya manusia, dan 
teknologi (Rusmin, 2010). Penelitian sebelumnya menemukan bahwa bahwa variabel kualitas audit tidak berpengaruh signifikan terhadap praktik manajemen laba (Luhgiatno, 2010). Tetapi hasil tersebut berbeda dengan kesimpulan yang diperoleh Rusmin (2010) dan Gerayli (2011) yang menyatakan bahwa perusahaan yang diaudit oleh KAP yang berafiliasi dengan big four memiliki nilai discretionary accruals yang lebih rendah dibandingkan dengan perusahaan yang diaudit oleh KAP non big four. Berdasarkan uraian tersebut, dalam penelitian ini diajukan hipotesis sebagai berikut:

\section{$\mathrm{H}_{2}$ : Kualitas audit berpengaruh terhadap manajemen laba.}

\section{METODE PENELITIAN}

\section{Populasi, Sampel dan Pengumpulan Data}

Penelitian ini menggunakan data sekunder berupa laporan keuangan perusahaan manufaktur Indonesia yang listing di BEI selama tahun 2007 sampai dengan tahun 2011. Teknik pengambilan sampel dilakukan secara purposive sampling yaitu dengan kriteria (1) Perusahaan manufaktur go public dan masih terdaftar sebagai emiten pada BEI sampai tanggal 31 Desember 2011; (2) Perusahaan mempublikasikan laporan keuangan secara lengkap untuk periode 2006 sampai 2011 yang dinyatakan dalam Rupiah; (3) Perusahaan menerbitkan laporan keuangan dengan tahun buku yang berakhir tanggal 31 Desember. Berdasarkan kriteria tersebut diperoleh sampel sebanyak 103 perusahaan dengan periode pengamatan selama lima tahun.

\section{Definisi Operasional dan Pengukuran Variabel Variabel Independen}

Free Cash Flow merupakan arus kas aktual yang didistribusikan kepada investor sesudah perusahaan melakukan semua investasi dan modal kerja yang diperlukan untuk menjaga kelangsungan operasionalnya (Sawir, 2004:93). Variabel ini dihitung dengan menggunakan rumus Brigham dan Houston (2004:67), yaitu :

\section{Free Cash Flow $=$ NOPAT - investasi bersih pada modal operasi}

Keterangan:

NOPAT (net operating profit after tax $)=$ EBIT $(1-$ tarif pajak)

Investasi bersih modal operasi $\quad=$ Total modal operasi $i_{t}-$ total modal

operasi $\mathrm{t}_{\mathrm{t}-1}$

Total modal operasi

bersih

Modal kerja operasi bersih $\quad=$ Aset lancar - kewajiban lancar tanpa bun 
Kualitas Audit diproksikan dengan ukuran KAP yang dibedakan menjadi KAP Big Four dan KAP non-Big Four. KAP yang berafiliasi dengan The Big Four dianggap dapat memberikan jaminan yang lebih besar kepada investor mengenai integritas pelaporan keuangan yang diaudit (Gerayli, 2011). Kualitas audit diukur dengan skala nominal melalui variabel dummy. Angka 1 digunakan untuk mewakili perusahaan yang diaudit oleh KAP Big Four dan angka 0 digunakan untuk mewakili perusahaan yang diaudit oleh KAP non-Big Four (Rusmin, 2010; Gerayli, 2011).

\section{Variabel Kontrol}

Ukuran perusahaan adalah besar kecilnya perusahaan, pada penelitian ini ukuran perusahaan diukur dari jumlah total aset perusahaan sampel. dengan menggunakan log natural dari total asset. Total aset digunakan sebagai proksi ukuran perusahaan dengan pertimbangan total aset perusahaan relatif lebih stabil dibandingkan dengan jumlah penjualan dan nilai kapitalisasi pasar (Guna dan Herawaty, 2010).

\section{Variabel Dependen}

Manajemen Laba dihitung dengan menggunakan rumus the modified jones model untuk memperoleh nilai discretionary accruals sebagai proksi manajemen laba, karena model ini banyak digunakan dalam penelitian akuntansi dan merupakan model yang paling baik dalam mendeteksi manajemen laba serta memberikan hasil yang paling kuat (Sulistiawan dkk, 2011:73). Discretionary accruals dihitung dengan menggunakan rumus sebagai berikut:

$$
\mathrm{TAC}_{\text {it }}=\mathrm{N}_{\mathrm{it}}-\mathrm{CFO}_{\mathrm{it}}
$$

Nilai total accrual (TA) diestimasi dengan persamaan regresi linear berganda yang berbasis ordinary least square (OLS) sebagai berikut:

$$
\mathrm{TAC}_{\mathrm{it}} / \mathrm{A}_{\mathrm{it}-1}=\beta_{1}\left(1 / \mathrm{A}_{\mathrm{it}-1}\right)+\beta_{2}\left(\Delta \mathrm{REV}_{\mathrm{t}} / \mathrm{A}_{\mathrm{it}-1}\right)+\beta_{3}\left(\mathrm{PPE}_{\mathrm{t}} / \mathrm{A}_{\mathrm{it}-1}\right)+\mathrm{e}
$$

Dengan menggunakan koefisien regresi diatas nilai non discretionary accruals (NDA) dapat dihitung dengan rumus :

$$
\mathrm{NDA}_{\mathrm{it}}=\beta_{1}\left(1 / \mathrm{A}_{\mathrm{it}-1}\right)+\beta_{2}\left(\Delta \mathrm{REV}_{\mathrm{t}} / \mathrm{A}_{\mathrm{it}-1}-\Delta \mathrm{REC}_{\mathrm{t}} / \mathrm{A}_{\mathrm{it}-1}\right)+\beta_{3}\left(\mathrm{PPE}_{\mathrm{t}} / \mathrm{A}_{\mathrm{it}-1}\right)
$$

Selanjutnya discretionary accrual (DA) dapat dihitung sebagai berikut:

$$
\mathrm{DA}_{\mathrm{it}}=\mathrm{TA}_{\mathrm{it}} / \mathrm{A}_{\mathrm{it}-1}-\mathrm{NDA}_{\mathrm{it}}
$$

Keterangan :

$\mathrm{TAC}_{\mathrm{it}}=$ Total accruals perusahaan $\mathrm{i}$ pada periode $\mathrm{t}$

$\mathrm{N}_{\mathrm{it}} \quad=$ Laba bersih perusahaan $\mathrm{i}$ pada periode $\mathrm{t}$ 
$\mathrm{CFO}_{\text {it }}=$ Aliran kas dari aktivitas operasi perusahaan $\mathrm{i}$ pada periode $\mathrm{t}$

$\mathrm{A}_{\mathrm{it}-1}=$ Total aset perusahaan $\mathrm{i}$ pada tahun $\mathrm{t}-1$

$\triangle \mathrm{REV}_{\mathrm{t}}=$ Perubahan pendapatan perusahaan $\mathrm{i}$ dari tahun $\mathrm{t}-1$ ke tahun $\mathrm{t}$

$\triangle \mathrm{REC}_{\mathrm{t}}=$ Perubahan piutang perusahaan $\mathrm{i}$ dari tahun $\mathrm{t}-1$ ke tahun $\mathrm{t}$

PPEt $=$ Aset tetap ( property, plant and equipment) perusahaan tahun $\mathrm{t}$

$\mathrm{DA}_{\mathrm{it}} \quad=$ Discretionary Accruals perusahaan i pada periode ke $\mathrm{t}$

$\mathrm{NDA}_{\mathrm{it}}=$ Non Discretionary Accruals perusahaan i pada periode ke $\mathrm{t}$

$\beta_{1}, \beta_{2}, \beta_{3}=$ Koefisien regresi

$\mathrm{e}=$ error

Alat analisis yang digunakan untuk menguji hipotesis adalah multiple regression analysis dengan model persamaan sebagai berikut:

$\mathrm{DA}=\beta_{0}+\beta_{1} \mathrm{FCF}+\beta_{2} \mathrm{KA}+\beta_{3} \mathrm{SIZE}+\mathrm{e}$

Keterangan: DA: Discretionary Accruals, FCF : Arus Kas Bebas, KA : Kualitas Audit, SIZE : Ukuran Perusahaan, e : Koefisien Error.

\section{HASIL DAN PEMBAHASAN}

Pengujian Asumsi Klasik

Hasil pengujian normalitas dengan uji statistik non-parametrik Kolmogorov Smirnov menunjukkan bahwa besarnya nilai Kolmogorov-Smirnov adalah 3,351 dan signifikan pada 0,000 . Tingkat signifikansi menunjukkan nilai di bawah 0,005 , hal ini berarti bahwa data tidak terdistribusi secara normal. Data yang tidak terdistribusi secara normal tersebut mengindikasikan bahwa ada beberapa data outlier (data ekstrim). Oleh karenanya dilakukan pengujian terhadap data outlier ini bisa dilakukan dengan Casewise Diagnostics yang terdapat di program SPSS. Setelah melalui proses tersebut, diketahui total data yang digunakan dalam analisa regresi dan terbebas dari outlier adalah sebanyak 487 observasi. Setelah data outlier tersebut dikeluarkan dari observasi, kemudian dilakukan uji normalitas kembali, dan dapat diketahui bahwa data telah terdistribusi secara normal. Hal ini ditunjukkan oleh nilai signifikansi Kolmogorov-Smirnov yang berada di atas 0.05 yaitu sebesar 0.065 .

\section{Tabel 1. Uji Kolmogorov-Smirnov II}

\begin{tabular}{lc}
\hline \multicolumn{1}{c}{ Indikasi } & Unstandardized Residual \\
\hline Kolmogorov-Smirnov Z & 1,471 \\
Signifikansi & 0,062 \\
\hline
\end{tabular}

Sumber: Data diolah

Terkait pengujian asumsi klasik lainnya, yaitu multikolinearitas, autokorelasi dan heteroskedastisitas, tidak ditemui adanya gejala-gejala penyimpangan atas asumsi tersebut dalam model yang diuji atau bisa dikatakan bahwa data dalam model regresi 
penelitian ini telah memenuhi uji asumsi klasik. Hasil selengkapnya tersaji dalam lampiran yang terkait.

\section{Pengujian Hipotesis}

Berdasarkan hasil uji statistik, diketahui nilai F sebesar 24,790 dengan tingkat signifikansi 0,000 $(<0,05)$ Hal ini berarti bahwa variabel independen yang terdiri dari free cash flow dan kualitas audit, serta variabel kontrol ukuran perusahaan secara bersama-sama berpengaruh secara signifikan terhadap variabel dependen yakni praktik manajemen laba. Hal ini menunjukkan bahwa model regresi dalam penelitian ini benar-benar dapat diterima dan digunakan untuk memprediksi.

Model regresi yang dikembangkan untuk menguji hipotesis-hipotesis yang telah dirumuskan dalam penelitian ini adalah:

$$
\mathrm{DA}=-0,138-0,176 \mathrm{FCF}-0,014 \mathrm{KA}+0,005 \mathrm{SIZE}+\mathrm{e}
$$

Dari model regresi tersebut dapat diketahui bahwa variabel free cash flow (FCF), dan kualitas audit (KA) memiliki arah yang berlawanan (pengaruh negatif) terhadap manajemen laba (DA). Hal ini berarti bahwa jika variabel FCF dan KA mengalami peningkatan satu satuan maka DA akan menurun sebesar koefisien dari masing-masing variabel tersebut, dan begitu juga sebaliknya, dengan asumsi variabel lainnya konstan. Sedangkan untuk variabel ukuran perusahaan (SIZE) memiliki arah yang searah (berpengaruh positif) terhadap manajemen laba (DA). Hal ini berarti jika variabel SIZE mengalami peningkatan satu satuan maka DA juga akan meningkat sebesar 0,005, dan begitu pula sebaliknya.

\section{Tabel 2. Uji Statistik t}

\begin{tabular}{cccc}
\hline Model & Koefisien & T & Sig. \\
\hline (Constant) & $-0,138$ & $-1,673$ & 0,095 \\
FCF & $-0,176$ & $-9,350$ & 0,000 \\
KA & $-0,013$ & $-1,389$ & 0,166 \\
SIZE & 0,005 & 1,686 & 0,092 \\
\hline
\end{tabular}

Sumber: Data diolah

Berdasarkan hasil uji hipotesis t pada tabel 2 di atas, dapat diketahui bahwa untuk variabel arus kas bebas (free cash flow) berpengaruh negatif terhadap manajemen laba dilihat dari hasil analisis regresi diperoleh nilai $t$ hitung sebesar 9,350 dengan tingkat signifikansi sebesar $0,000(<0,05)$ yang berarti $\mathrm{H}_{1}$ diterima. Nilai koefisien regresi variabel free cash flow yang negatif tersebut menunjukkan jika nilai koefisien variabel lainnya tetap, maka perubahan free cash flow satu satuan akan menyebabkan penurunan pada manajemen laba. 


\section{Pembahasan}

\section{Pengaruh Free cash flow berpengaruh terhadap manajemen laba.}

Berdasarkan hasil analisis dapat disimpulkan bahwa free cash flow berpengaruh negatif signifikan terhadap manajemen laba. Arus kas bebas (free cash flow) merupakan arus kas aktual yang bisa didistribusikan kepada investor sesudah perusahaan melakukan semua investasi dan modal kerja yang diperlukan untuk menjaga kelangsungan operasionalnya (Sawir, 2004:93). Hasil penelitian ini konsisten dengan penelitian oleh Isnawati (2011) yang menyatakan bahwa FCF berpengaruh negatif signifikan terhadap manajemen laba. Pengaruh negatif tersebut dikarenakan free cash flow merupakan determinan penting dalam penentuan nilai perusahaan, sehingga manajer perusahaan lebih terfokus pada usaha untuk meningkatkan free cash flow.

Fokus sebagian besar investor pada informasi arus kas perusahaan. Informasi arus kas mampu menunjukkan kemampuan perusahaan dalam membagikan deviden. Pada arus kas yang tinggi, perusahaan sudah bisa meningkatkan harga saham karena investor melihat bahwa perusahaan tersebut mempunyai kelebihan kas untuk pembagian deviden (Mardiyanto, 2008:281). White et al. (2003:68) mengungkapkan bahwa semakin besar free cash flow yang tersedia dalam suatu perusahaan, maka semakin sehat perusahaan tersebut karena memiliki kas yang tersedia untuk pertumbuhan, pembayaran hutang, dan deviden. Hal ini juga dapat diartikan bahwa semakin kecil nilai FCF yang dimiliki perusahaan, maka perusahaan tersebut bisa dikategorikan semakin tidak sehat. Oleh karena sebagian besar investor lebih terfokus pada informasi arus kas bebas perusahaan maka pada perusahaan dengan nilai free cash flow yang tinggi cenderung tidak akan melakukan manipulasi laba.

\section{Kualitas audit berpengaruh terhadap manajemen laba.}

Berdasarkan analisis statistik, kualitas audit tidak berpengaruh terhadap manajemen laba. Praktik manajemen laba ini terjadi karena pihak manajemen perusahaan memiliki keinginan/motivasi yang kuat agar kinerja keuangan tampak bagus dimata calon investor, sehingga mengabaikan keberadaan auditor big four. De Angelo (1981) menyatakan bahwa audit dipengaruhi oleh ukuran kantor auditor eksternal. KAP yang berafiliasi dengan big four mewakili besarnya ukuran kantor auditor eksternal. Namun terdapat indikasi bahwa kualitas audit sebuah kantor akuntan publik yang digunakan sebuah perusahaan, tidak menjamin berkurangnya tindakan perusahaan melakukan praktek manajemen laba.

Hal tersebut dikarenakan tidak semua auditor eksternal dari KAP yang berskala besar mempunyai kemampuan yang baik dalam bidang audit, sehingga memungkinkan proses audit yang tidak sempurna yang mengakibatkan kurangnya integritas suatu laporan keuangan. Kualitas audit juga tergantung dimilikinya auditor yang berkompeten dan independen pada kantor akuntan big four. Hasil penelitian ini sesuai dengan penelitian Luhgiatno (2010). 


\section{SIMPULAN DAN SARAN}

\section{Simpulan}

Berdasarkan hasil penelitian dapat diperoleh kesimpulan bahwa free cash flow berpengaeuh negatif terhadap manajemen laba, hal ini dikarenakan free cash flow merupakan determinan penting dalam penentuan nilai perusahaan, sehingga manajer perusahaan lebih terfokus pada usaha untuk meningkatkan free cash flow. Perusahaan dengan arus kas bebas yang tinggi cenderung tidak akan melakukan manajemen laba, karena meskipun tanpa adanya manajemen laba, perusahaan sudah bisa meningkatkan harga sahamnya karena investor melihat bahwa perusahaan tersebut mempunyai kelebihan kas untuk pembagian deviden.

Kualitas audit tidak berpengaruh terhadap manajemen laba. Kualitas audit sebuah kantor akuntan publik yang digunakan sebuah perusahaan, tidak menjamin berkurangnya perusahaan melakukan praktek manajemen laba. Praktik manajemen laba ini terjadi karena pihak manajemen perusahaan mempunyai keinginan kinerja perusahaan tampak lebih bagus dari kondisi sesungguhnya. Keinginan yang kuat menampakkan kinerja keuangan yang bagus dimata calon investor, sehingga mengabaikan keberadaan auditor big four.

Penelitian ini mempunyai beberapa keterbatasan yang perlu diperhatikan untuk penelitian berikutnya, yaitu (1) Perusahaan yang dipilih menjadi populasi dan sampel hanya dari sektor manufaktur sehingga hasil penelitian hanya berlaku pada perusahaan yang ditentukan oleh peneliti dan tidak dapat dijadikan acuan untuk melakukan generalisasi pada seluruh perusahaan publik yang terdaftar di BEI; (2) variabel independen hanya mampu menjelaskan $16.4 \%$ dari variabel dependen, sedangkan sisanya dipengaruhi oleh variabel-variabel lain yang belum diteliti.

\section{Saran}

Saran untuk penelitian selanjutnya adalah (1) menambah populasi perusahaan yang akan dijadikan sampel peneltian tidak hanya perusahaan manufaktur tetapi juga jenis industri lainnya yang terdaftar di Bursa Efek Indonesia; (2) menambahkan variabel independen lainnya di luar penelitian ini yang bisa mempengaruhi manajemen laba, misalnya kompensasi bonus, profitabilitas, fee audit, dan cash flow from operation. 


\section{DAFTAR PUSTAKA}

AAA Financial Accounting Standard Committee. 2001. SEC Auditor Independence Requirements. Accounting Horizons, 15(4): 373-386

Bapepam. 2004. Peraturan IX.I.5. Pembentukan dan Pedoman Pelaksanaan Kerja Komite Audit. Jakarta: Badan Pengawas Pasar Modal.

Belkaoui, Ahmed Riahi. 2004. Accounting Theory (Teori Akuntansi). Edisi ke lima. Terjemahan oleh Ali Akbar Yulianto dan Krista. 2007. Jakarta: Salemba Empat.

Brigham, Eugene F \& Joel F. Houston. 2004. Fundamentals Of Financial Management. Dasar-dasar Manajemen Keuangan. Edisi 10, buku 1. Terjemahan oleh Ali Akbar Yulianto. 2009. Jakarta: Salemba Empat.

Bukit, R. B. \& T. M Iskandar. 2009. Surplus Free Cash Flow, Earnings Management and Audit Committee. Int. Journal of Economics and Management, 3(1): 204 $-223$.

Chung R., Firth M. \& Kim, J.B. 2005. Earnings Management, Surplus Free Cash Flow, and External Monitoring. Journal of Business Research, 58(6): 766776.

De Angelo, L.E. 1981. Auditor Size and Audit Quality. Journal of Accounting and Economics, 3(1981): 183-199.

Gerayli, M.S., Abolfazl, M.Y \& Ali Reza M. 2011. Impact of Audit Quality on Earnings Management: Evidence from Iran. Int. Research Journal of Finance and Economics, Vol.66: 77-84.

Ghozali, Imam \& Anis Chariri. 2007. Teori Akuntansi. Semarang: Badan Penerbit Universitas Diponegoro.

Guna, Welvin I \& Arleen Herawaty. 2010. Pengaruh Mekanisme Good Corporate Governance, Independensi Auditor, Kualitas Audit dan Faktor Lainnya Terhadap Manajemen Laba. Jurnal Bisnis Dan Akuntansi, 12 (1): 53-68.

Isnawati. 2011. Pengaruh Free Cash Flow Dan Growth Terhadap Manajemen Laba Denganmoderasi Komisaris Independen. Tesis tidak diterbitkan. Surabaya Universitas Airlangga.

Luhgiatno. 2010. Pengaruh Kualitas Audit terhadap Manajemen Laba Studi Perusahaan yang melakukan IPO. Fokus Ekonomi, 5(2): 15-31.

Mardiyanto, Handono. 2008. Inti Sari Manajemen Keuangan. Jakarta: Grasindo.

Rusmin, R., 2010. Auditor Quality And Earnings Management: Singaporean evidence. Managerial Auditing Journal, 25(7): 618-638.

Sawir, Agnes. 2004. Kebijakan Pendanaan dan Restrukturisasi Perusahaan. Jakarta: PT. Gramedia Pustaka Utama.

Scott, William R. 2011. Financial Accounting Theory. Sixth Edition. Canada: Person Prentice Hall.

Sulistiawan, Dedhy, Yeni Januarsi \& Liza Alvia. 2011. Creative Accounting Mengungkap Manajemen Laba dan Skandal Akuntansi. Jakarta: Salemba Empat. 
Sulistyanto, Sri H. 2008. Manajemen Laba: Teori dan Model Empiris. Jakarta: Grasindo.

White, Gerald I., Sondhi, Ashwinpul C., \& Fried, Dov. 2003. The Analysis and Use Of Financial Statements. New York: John Wiley and Sons, Inc. 


\section{LAMPIRAN-LAMPIRAN}

\section{Descriptive Statistics}

\begin{tabular}{|l|r|r|r|r|r|}
\hline & $\mathrm{N}$ & Minimum & Maximum & \multicolumn{1}{c|}{ Mean } & Std. Deviation \\
\hline DA & 515 & -1.0394 & 2.8284 & .001863 & .2013621 \\
FCF & 515 & -3.6107 & 3.6077 & .017238 & .3213409 \\
SIZE & 515 & 23.1886 & 32.6649 & 27.607200 & 1.5036160 \\
Valid N (listwise) & 515 & & & & \\
& & & & & \\
\hline
\end{tabular}

KA

\begin{tabular}{|rl|r|r|r|r|}
\hline & & & & \multicolumn{2}{c|}{$\begin{array}{c}\text { Cumulative } \\
\text { Percent }\end{array}$} \\
\hline Valid & 0 & 311 & 60.4 & 60.4 & 60.4 \\
& 1 & 204 & 39.6 & 39.6 & 100.0 \\
& Total & 515 & 100.0 & 100.0 & \\
\hline
\end{tabular}

Model Summary

\begin{tabular}{|l|r|r|r|r|r|}
\hline Model & $\mathrm{R}$ & $\mathrm{R}$ Square & \multicolumn{1}{c|}{$\begin{array}{c}\text { Adjusted R } \\
\text { Square }\end{array}$} & $\begin{array}{c}\text { Std. Error of the } \\
\text { Estimate }\end{array}$ & Durbin-Watson \\
\hline 1 & $.413^{\mathrm{a}}$ & .171 & .164 & .0867658 & 1.965 \\
\hline
\end{tabular}

a. Predictors: (Constant), SIZE, FCF, LEV, KA

b. Dependent Variable: DA

ANOVA $^{\mathrm{D}}$

\begin{tabular}{|ll|r|r|r|r|r|}
\hline Model & Sum of Squares & df & Mean Square & F & Sig. \\
\hline 1 & Regression & .746 & 4 & .187 & 24.790 & $.000^{\mathrm{a}}$ \\
& Residual & 3.629 & 482 & .008 & & \\
& Total & 4.375 & 486 & & & \\
\hline
\end{tabular}

a. Predictors: (Constant), SIZE, FCF, LEV, KA

b. Dependent Variable: DA

\section{Coefficients $^{a}$}

\begin{tabular}{|c|c|c|c|c|c|c|c|}
\hline \multirow[b]{2}{*}{ Model } & \multicolumn{2}{|c|}{$\begin{array}{l}\text { Unstandardized } \\
\text { Coefficients }\end{array}$} & \multirow{2}{*}{\begin{tabular}{|c|}
$\begin{array}{c}\text { Standardized } \\
\text { Coefficients }\end{array}$ \\
Beta \\
\end{tabular}} & \multirow[b]{2}{*}{$\mathrm{t}$} & \multirow[b]{2}{*}{ Sig. } & \multicolumn{2}{|c|}{ Collinearity Statistics } \\
\hline & B & Std. Error & & & & Tolerance & VIF \\
\hline (Constant) & -.138 & .083 & & -1.673 & .095 & & \\
\hline
\end{tabular}




\begin{tabular}{|c|c|c|c|c|c|c|c|}
\hline FCF & -.176 & .019 & -.392 & -9.350 & .000 & .979 & 1.021 \\
\hline $\mathrm{KA}$ & -.013 & .009 & -.067 & -1.389 & .166 & .745 & 1.342 \\
\hline SIZE & .005 & .003 & .080 & 1.686 & .092 & .761 & 1.314 \\
\hline
\end{tabular}

a. Dependent Variable: DA

Histogram

Dependent Variable: DA

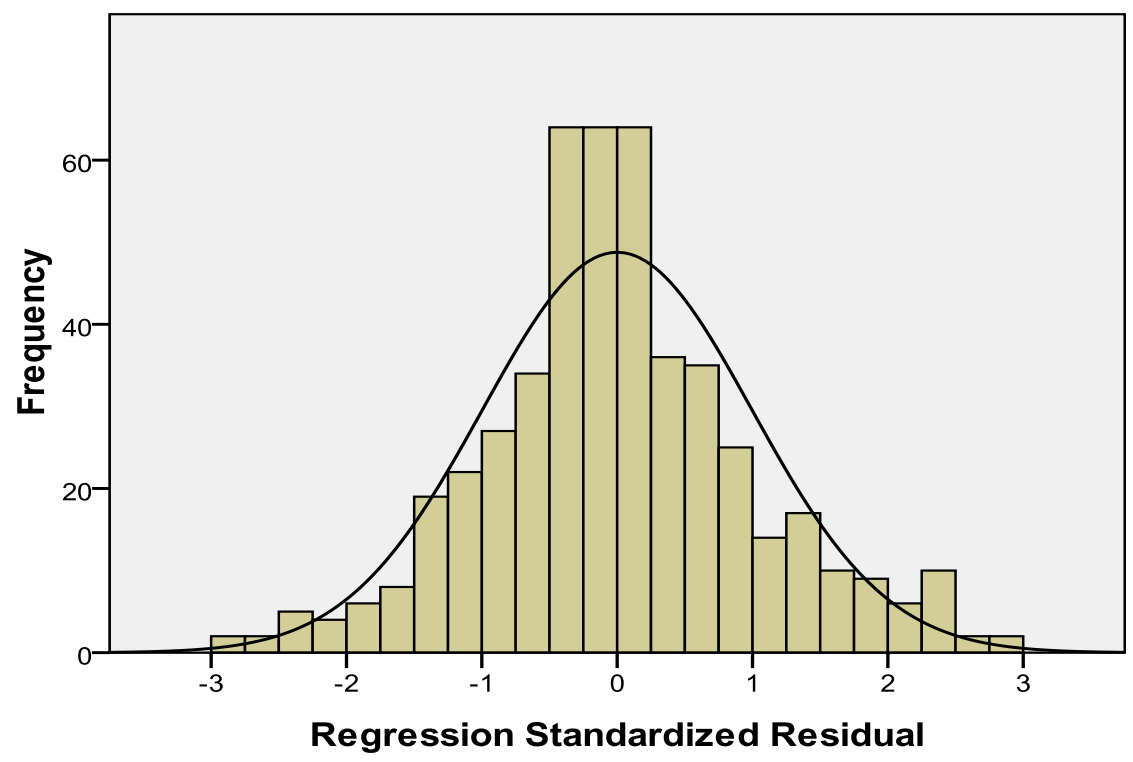

Mean $=2.21 \mathrm{E}-17$

Std. Dev. $=0.996$ $\mathrm{N}=487$

\begin{tabular}{|ll|r|}
\hline \multicolumn{2}{|c|}{ One-Sample Kolmogorov-Smirnov Test } \\
\hline N & & $\begin{array}{c}\text { Unstandardized } \\
\text { Residual }\end{array}$ \\
Normal Parameters ${ }^{\mathrm{a}, \mathrm{b}}$ & Mean & 487 \\
& Std. Deviation & .0000000 \\
Most Extreme Differences & Absolute & .08640796 \\
& Positive & .067 \\
& Negative & .067 \\
Kolmogorov-Smirnov Z & & -.047 \\
Asymp. Sig. (2-tailed) & & 1.471 \\
& & .062 \\
\hline
\end{tabular}

a. Test distribution is Normal.

b. Calculated from data. 